\title{
Profile and entrepreneurial intention of nursing students: a comparison between Brazil and Chile
}

\author{
Perfil e intenção empreendedora de estudantes de enfermagem: comparativo entre Brasil e Chile \\ Perfil e intenciones emprendedoras de estudiantes de enfermería: comparativo entre Brasil y Chile
}

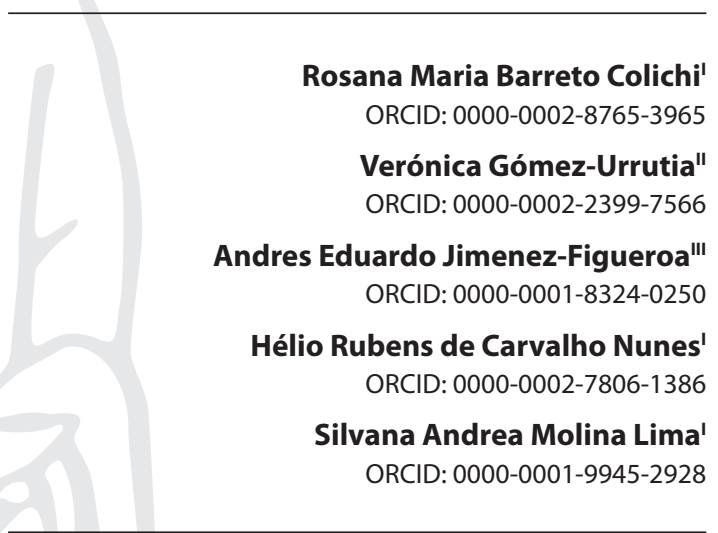

'Universidade Estadual Paulista Júlio de Mesquita Filho.

Botucatu, São Paulo, Brazil

"Universidad Autónoma de Chile, Talca, Chile. "I Universidad de Talca, Talca, Chile.

How to cite this article: Colichi RMB, Gómez-Urrutia V, Andres Eduardo Jimenez-Figueroa AE, Nunes HRC, Lima SAM. Profile and entrepreneurial intention of nursing students: a comparison between Brazil and Chile. Rev Bras Enferm. 2020;73(6):e20190890. doi: http://dx.doi.org/10.1590/0034-7167-2019-0890

Corresponding author: Rosana Maria Barreto Colichi E-mail: rosana.barreto-colichi@unesp.br

EDITOR IN CHIEF: Antonio José de Almeida Filho ASSOCIATE EDITOR: Hugo Fernandes

Submission: 03-05-2020

Approval: 04-02-2020

\begin{abstract}
Objective: to identify and compare factors associated with profile, intentions, motivations, and barriers to entrepreneurial behavior of nursing students from Brazil and Chile. Methods: this cross-sectional study was carried out between March and September 2018 including 889 nursing students. A form was used to assess the socio-demographic profile, professional claims, entrepreneurial intentions and motivations. Statistical analysis used Chi-Square and Fisher's Exact tests, with a 5\% significance level, and a simple logistic regression model. Results: there are significant differences between countries in the profile of students and in the motivations studied, but not in professional pretensions and entrepreneurial intentions. Lack of education on the subject reveals itself as an important barrier to entrepreneurship. Conclusion: given the lack of teaching entrepreneurship in undergraduate nursing courses and the characteristics inherent to students, education must be appropriate to different cultures to prepare future professionals for other areas of practice.

Descriptors: Employment; Entrepreneurship; Education, nursing; Students, Nursing; Intention.
\end{abstract}

\section{RESUMO}

Objetivo: identificar e comparar os fatores associados ao perfil, intenções, motivações e barreiras ao comportamento empreendedor de estudantes de enfermagem do Brasil e Chile. Métodos: estudo transversal, realizado entre março e setembro de 2018, incluindo 889 estudantes de enfermagem. Utilizou-se formulário para avaliação do perfil sociodemográfico, pretensões profissionais, intenções e motivações empreendedoras. Na análise estatística, foram utilizados os testes Qui-Quadrado e Exato de Fisher, com nível de significância 5\%, e modelo de regressão logística simples. Resultados: há diferenças significativas entre os países no perfil dos alunos e nas motivações estudadas, mas não nas pretensões profissionais e intenções empreendedoras. Falta de ensino sobre o tema revela-se como importante barreira ao empreendedorismo. Conclusão: diante da carência no ensino de empreendedorismo nos cursos de graduação em enfermagem e das características inerentes aos estudantes dessa área, o ensino deve estar adequado às diferentes culturas para preparar os futuros profissionais para outras áreas de atuação.

Descritores: Mercado de Trabalho; Contrato de Risco; Estudantes de Enfermagem; Educação em Enfermagem; Intenção.

\section{RESUMEN}

Objetivo: identificar y comparar los factores asociados con el perfil, intenciones, motivaciones y barreras al comportamiento emprendedor de estudiantes de enfermería de Brasil y Chile. Métodos: estudio transversal, realizado entre marzo y septiembre de 2018, que incluyó a 889 estudiantes de enfermería. Se utilizó un formulario para evaluar el perfil sociodemográfico, los reclamos profesionales, las intenciones y motivaciones empresariales. En el análisis estadístico, se utilizaron las pruebas exactas de Chi-Cuadrado y de Fisher, con un nivel de significancia de $5 \%$ y un modelo de regresión logística simple. Resultados: existen diferencias significativas entre países en el perfil de los estudiantes y en las motivaciones estudiadas, pero no en intenciones profesionales e intenciones empresariales. La falta de educación sobre el tema demuestra ser una barrera importante para el emprendimiento. Conclusión: dada la falta de enseñanza del emprendimiento en los cursos de pregrado en enfermería y las características inherentes a los estudiantes en esta área, la educación debe ser apropiada para diferentes culturas para preparar a los futuros profesionales para otras áreas de especialización.

Descriptores: Mercado de Trabajo; Contrato de Riesgo; Estudiantes de Enfermería; Educación en Enfermería; Intención. 


\section{INTRODUCTION}

In a global context that includes new stages of globalization, democracy, citizenship, security, longevity, and cultural changes, it is evident that in the scope of education, it is necessary to train tolerant, creative people, with an entrepreneurial spirit, capable of solving problems ${ }^{(1)}$.

In this sense, training of nurses includes administration and management to guarantee such competencies. Professionals must be able to perform it with regard to physical and material resources, workforce and information, as well as they must be able to be managers, employers or leaders in the health team ${ }^{(2)}$.

The leadership position placed by nurses also represents an opportunity to disseminate entrepreneurial culture in the various sectors of professional activity in the form of intrapreneurship, social entrepreneurship or even business entrepreneurship. In this study, we will consider business entrepreneurship, which is related to the opening of its own company, autonomous practices that require self-management and vision of opportunities ${ }^{(3)}$.

In the management of their own company, employing other health professionals, nurses also act as economic, social and political agents. In addition to being able to improve income and acquire greater independence at work, companies opened by nurses reflect new labor markets and the expansion of these professionals' performance in the current setting.

However, the historical-cultural context of the countries seems to act in the choice of nursing undergraduate sit-ins, relating it to assistance and care, distancing itself from socioeconomic and business aspirations, as occurs in other professions ${ }^{(4)}$. Studies conducted so far report numerous barriers (cultural, political, structural), however, little is understood or known alternatives capable of solving them, and answers have been shown to be insufficient to promote entrepreneurship in nursing ${ }^{(5)}$.

Therefore, the complexity that involves entrepreneurship and barriers imposed in nursing imposes the need for integrated studies, multiplying perspectives. Unlike restrictive thoughts, investigations become even more intriguing and necessary ${ }^{(6)}$. To support public education and health policies aimed also at economic growth, it is necessary to observe the factors that can act on the entrepreneurial intentions of future nurses in different countries and contexts and how they can impact their academic education.

According to the National Entrepreneurship Context Index (NECl), created by the Global Entrepreneurship Monitor (GEM) project that assesses the environment for entrepreneurship in several countries, Chile ranks $26^{\text {th }}$ out of 54 economies studied. On the other hand, with particularly low scores regarding government support, taxes and bureaucracy, suggesting restrictions on activity such as the growth of a business, Brazil shows results that place it among the lowest ranked economies $\left(48^{\text {th }}\right)^{(7)}$.

Chile has excelled in entrepreneurship in several respects in recent years. With one of the highest rates of total early-stage entrepreneurial activity (TEA) among high-income countries (25\%) and high rates of opportunity perception for new ventures that exceeds $50 \%$, it still occupies the first place in the innovation item. Entrepreneurs are introducing products and services that are new to customers and generally not offered by competitors. However, discontinuity rates are high, where interruption of a business is mainly due to the lack of profitability or capital( ${ }^{(7-8)}$.
In Brazil, TEA (17.9\%) and established commercial property (20.2\%) exhibit a gradual increase in recent decades, resulting from the political and economic environment in the country, providing higher levels of entrepreneurial activity, including sustainable activities and corporate ownership rates. Despite this, expectations of growth and innovation are considered low, as only $31 \%$ of adults think there are good opportunities to start business ${ }^{(7,9)}$.

While in Chile the rate of entrepreneurial intentions is close to $50 \%$, in Brazil it is only $25 \%$, which is one of the closest indicators of entrepreneurial potential in a society (GEM 2018) $)^{(7)}$. For this reason, business intentions, that is, the desire to open business has been the object of study in entrepreneurship ${ }^{(10)}$. Deepening knowledge about intentions, motivations and perceptions about the entrepreneurial behavior of nursing students allows generating adequate knowledge in order to design political and pedagogical strategies capable of integrating the academic environment to market realities, besides contributing to the generation of better jobs and economy of countries ${ }^{(6)}$.

It is popular knowledge that the health area is distinguished by its vocation of service and has offered profitability in terms of monthly income and percentage of employability.

In Chile, among the most sought-after careers we can find nursing, which in addition to having the lowest dropout rate in that country (17\% give up in the first year) ${ }^{(11)}$, has been guaranteeing employment in several areas (care, management, education and research); and remarkable economic solvency for those integrated into the labor market until a few years ago. However, this setting has been changing, being reduced by the overpopulation of nurses in the labor market, given the number of universities and vocational institutes that provide the career.

In Brazil, in addition to the increase in nursing courses in recent years, the setting has also been changing as health denationalization in the various spheres of government grows. Strategies such as transferring public funds to the private sector ${ }^{(12)}$, complementary participation of the private sector and hiring indirect management (through Social Health Organizations - SHO) have resulted in lower remuneration to nurses. On the other hand, by supplying the insufficiency of services in the public sector, outsourcing can be understood as a promising market for business entrepreneurs ${ }^{(5)}$.

In this context, and through the scarcity of current and in-depth reports in the literature about entrepreneurship in nursing in Brazil and Chile, the question is: are there differences between the factors associated with profile, intentions, motivations, and barriers to entrepreneurial behavior of nursing students in Brazil and Chile?

\section{OBJECTIVE}

To identify and compare the factors associated with profile, intentions, motivations, and barriers to entrepreneurial behavior of nursing students from Brazil and Chile.

\section{METHODS}

\section{Ethical aspects}

Ethical aspects have been preserved as provided for in the legislation of both countries. In Brazil, the Research Ethics Committee of 
UNESP's Faculdade de Medicina de Botucatu approved the research. In Chile, the project that includes this research had approval by the Ethics Committee of Universidad Autónoma de Chile by Acta de Evaluación 75-18. All participants signed a consent form.

\section{Study design, period and location}

This is a cross-sectional analytical study, guided by the STROBE tool. Data collection was performed from March to September 2018 in five nursing higher education institutions (HEls) based in the countryside of the state of São Paulo, Brazil and in the Maule region of Chile, two public universities (one in each country) and three private entities (two Brazilian and one Chilean).

\section{Population/sample; inclusion and exclusion criteria}

The inclusion criteria were being a nursing undergraduate student, present on the day of the interview and agreeing to participate in the research. Altogether, 1,196 subjects met the inclusion criteria. Since the design was cross-sectional and, therefore, subjects were not followed longitudinally, there was no definition of exclusion criteria. Based on the above criteria, sample is considered non-probabilistic of the intentional type, composed of $74.3 \%$ of the target population.

\section{Study protocol}

The data collection instrument, developed by researchers in Brazilian Portuguese and Spanish, was divided into three parts: 1) sociodemographic data; 2) questionnaire to collect information on the existence of a family businessman and future intentions of the interviewee, possible facilitating factors and most frequent barriers to entrepreneurship, according to an international bibliographic survey conducted preliminary by the authors; 3 ) spreadsheet to be filled with the citation of the maximum possibilities of areas of action in relation to the nurse's labor market.

For analysis of municipalities with entrepreneurial potential, we considered the number of companies present in each municipality using the official public data available. In the absence of this information, population served as a parameter to align similar sites in Brazil and Chile.

To evaluate insertion of entrepreneurship in the career and labor market vision, the words mentioned by the interviewees in the third part of the collection instrument were examined in search of terms related to entrepreneurship.

After authorization of the academic units, invitation to participate was made verbally during school hours of students, explaining that the study participation was voluntary. Forms were completed by each student with their self-assessment, which took about 20 minutes. They were coded, using numbering only to identify the country and public or private educational institution.

\section{Analysis of results, and statistics}

The comparison between Brazil and Chile in relation to profile, intentions, motivations, and barriers was made with Chi-Square and Fisher's Exact nonparametric tests. In each country, identification of the factors associated with the chance of students to answer that they intend to have their own business after the end of nursing graduation was performed by adjusting simple logistic regression models in each country. Differences and associations were considered statistically significant if $p<0.05$. Analysis was carried out with SPSS v21.0.

\section{RESULTS}

The study included 383 Brazilian and 506 Chilean students and $(n=889)$ most of them from private institutions $(54.7 \%)$. With a predominance of women (81.7\%), we observed a higher number of men attending nursing in Chile (23.3\%) compared to Brazil (11.7\%).

The prevalence of age was up to 25 years $(82.3 \%)$, had no affective partners $(89.1 \%)$ or children $(87.8 \%)$ and lived with their families $(76.1 \%)$, although with significant differences between the two countries.

Unlike in Brazil, most Chilean students came from subsidized private schools (54.2\%), received scholarships (71.3\%) and participates in research projects (42.0\%).

Students already inserted in the labor market represented almost half of the sample in Brazil (49.1\%), who worked mainly in organizations and in functions related to health, such as nursing assistant and technician, characteristics that are different from those observed among Chilean students.

Table 1 - Distribution of students' sociodemographic variables, intentions, motivations, and barriers to entrepreneurship, vision of career possibility related to entrepreneurship in Brazil and Chile

\begin{tabular}{|c|c|c|c|c|c|}
\hline \multirow{3}{*}{ Variables } & \multicolumn{4}{|c|}{ Country } & \multirow{3}{*}{$\begin{array}{c}p \\
\text { value }\end{array}$} \\
\hline & \multicolumn{2}{|c|}{$\begin{array}{c}\text { Brazil } \\
(n=383)\end{array}$} & \multicolumn{2}{|c|}{$\begin{array}{c}\text { Chile } \\
(n=506)\end{array}$} & \\
\hline & $\mathbf{n}$ & $\%$ & $\mathbf{n}$ & $\%$ & \\
\hline Males & 45 & 11.7 & 118 & 23.3 & $<0.001$ \\
\hline Private institution & 276 & 72.1 & 210 & 41.5 & $<0.001$ \\
\hline \multicolumn{6}{|l|}{ Age group } \\
\hline$\leq 19$ & 97 & 25.3 & 99 & 19.6 & $<0.001$ \\
\hline $20-25$ & 173 & 45.2 & 363 & 71.9 & $<0.001$ \\
\hline$\geq 26$ & 113 & 29.5 & 43 & 8.5 & $<0.001$ \\
\hline With partner & 91 & 23.8 & 6 & 1.2 & $<0.001$ \\
\hline With children & 85 & 22.2 & 24 & 4.8 & $<0.001$ \\
\hline \multicolumn{6}{|l|}{ Elementary school } \\
\hline Public institution & 279 & 73.0 & 211 & 41.8 & $<0.001$ \\
\hline Private subsidized & 0 & 0.0 & 260 & 51.5 & $<0.001$ \\
\hline Private & 103 & 27.0 & 34 & 6.7 & $<0.001$ \\
\hline \multicolumn{6}{|l|}{ High school } \\
\hline Public institution & 291 & 76.6 & 202 & 40.4 & $<0.001$ \\
\hline Private subsidized & 0 & 0.0 & 271 & 54.2 & $<0.001$ \\
\hline Private & 89 & 23.4 & 27 & 5.4 & $<0.001$ \\
\hline Enterprising city & 79 & 20.7 & 32 & 6.4 & $<0.001$ \\
\hline Working & 188 & 49.1 & 76 & 15.0 & $<0.001$ \\
\hline \multicolumn{6}{|l|}{ Work type } \\
\hline Nursing assistant & 16 & 8.6 & 1 & 1.4 & $<0.001$ \\
\hline Nursing technician & 50 & 26.9 & 1 & 1.4 & $<0.001$ \\
\hline Another function in health & 43 & 23.1 & 2 & 2.7 & $<0.001$ \\
\hline Outside the health area & 77 & 41.4 & 69 & 94.5 & $<0.001$ \\
\hline In health & 109 & 28.6 & 4 & 0.8 & $<0.001$ \\
\hline \multicolumn{6}{|l|}{ Residence } \\
\hline Living with family & 280 & 73.1 & 397 & 78.5 & $<0.001$ \\
\hline Living with other people & 12 & 3.1 & 94 & 18.6 & $<0.001$ \\
\hline Living alone & 32 & 8.4 & 13 & 2.6 & $<0.001$ \\
\hline
\end{tabular}


Profile and entrepreneurial intention of nursing students: a comparison between Brazil and Chile Colichi RMB, Gómez-Urrutia V, Andres Eduardo Jimenez-Figueroa AE, Nunes HRC, Lima SAM.

Table 1

\begin{tabular}{|c|c|c|c|c|c|}
\hline \multirow[t]{2}{*}{ Variables } & \multicolumn{2}{|c|}{$\begin{array}{c}\text { Brazil } \\
(n=383)\end{array}$} & \multicolumn{2}{|c|}{$\begin{array}{c}\text { Chile } \\
(n=506)\end{array}$} & \multirow[t]{2}{*}{$\begin{array}{c}p \\
\text { value }\end{array}$} \\
\hline & $\mathbf{n}$ & $\%$ & $\mathbf{n}$ & $\%$ & \\
\hline Participating in research project & 64 & 16.9 & 211 & 42.0 & $<0.001$ \\
\hline Scholarship grant & 89 & 23.2 & 361 & 71.3 & $<0.001$ \\
\hline With entrepreneur relative & 141 & 37.1 & 139 & 27.6 & $<0.001$ \\
\hline \multicolumn{6}{|l|}{ Future intentions } \\
\hline Do not know & 26 & 6.8 & 23 & 4.5 & 0.147 \\
\hline Non-health-related & 10 & 2.8 & 6 & 1.2 & 0.102 \\
\hline Continuing studies & 278 & 72.6 & 300 & 59.6 & $<0.001$ \\
\hline Professors & 31 & 8.1 & 27 & 5.3 & 0.099 \\
\hline Public hospital workers & 136 & 35.5 & 323 & 63.8 & $<0.001$ \\
\hline Private institution workers & 72 & 18.8 & 77 & 15.3 & 0.165 \\
\hline PHC workers & 0 & 0.0 & 17 & 3.4 & $<0.001$ \\
\hline NGO workers/volunteers & 2 & 0.5 & 3 & 0.6 & 0.889 \\
\hline Own business & 24 & 6.3 & 33 & 6.5 & 0.878 \\
\hline \multicolumn{6}{|l|}{ Motivation for intentions } \\
\hline Financial return & 97 & 25.4 & 20 & 4.0 & $<0.001$ \\
\hline Personal satisfaction & 200 & 52.2 & 245 & 48.4 & 0.262 \\
\hline Putting into practice & 127 & 33.2 & 86 & 17.0 & $<0.001$ \\
\hline Ease of study & 16 & 4.2 & 12 & 2.4 & 0.125 \\
\hline Desire to care for & 75 & 19.6 & 280 & 55.3 & $<0.001$ \\
\hline Third-party desire & 9 & 2.3 & 15 & 3.0 & 0.576 \\
\hline Professional stability & 99 & 25.8 & 69 & 13.6 & $<0.001$ \\
\hline Not into nursing & 1 & $0.3 \%$ & 5 & 1.0 & 0.190 \\
\hline No clear answer & 27 & $7.0 \%$ & 42 & 8.3 & 0.490 \\
\hline \multicolumn{6}{|l|}{ Reasons that lead to entrepreneurship } \\
\hline Financial return & 300 & 78.3 & 237 & 46.8 & $<0.001^{(1)}$ \\
\hline Personal satisfaction & 275 & 71.8 & 325 & 64.2 & $0.017^{(1)}$ \\
\hline Putting talents into practice & 159 & 41.5 & 147 & 29.1 & $<0.001^{(1)}$ \\
\hline Personality & 220 & 57.4 & 387 & 76.5 & $<0.001^{(1)}$ \\
\hline Financing & 37 & 9.7 & 87 & 17.2 & $0.001^{(1)}$ \\
\hline Country's economic stability & 39 & 10.2 & 66 & 13.0 & $0.191^{(1)}$ \\
\hline Outsourcing & 60 & 15.7 & 152 & 30.0 & $<0.001^{(1)}$ \\
\hline New technologies & 84 & 21.9 & 75 & 14.8 & $0.006^{(1)}$ \\
\hline Preceptor incentive & 26 & 6.8 & 25 & 4.9 & $0.241^{(1)}$ \\
\hline Undergraduate teaching & 70 & 18.3 & 96 & 19.0 & $0.792^{(1)}$ \\
\hline Government policies & 27 & 7.0 & 58 & 11.5 & $0.027^{(1)}$ \\
\hline Autonomy & 2 & 0.5 & 2 & 0.4 & $1.000^{(2)}$ \\
\hline Lack of job opportunity & 1 & 0.3 & 26 & 5.1 & $<0.001^{(2)}$ \\
\hline Desire to serve people & 0 & 0.0 & 2 & 0.4 & $0.509^{(2)}$ \\
\hline Desire to create jobs & 0 & 0.0 & 1 & 0.2 & $1.000^{(2)}$ \\
\hline Current working conditions & 1 & 0.3 & 3 & 0.6 & $0.638^{(2)}$ \\
\hline No response & 0 & 0.0 & 2 & 0.4 & $0.509^{(2)}$ \\
\hline \multicolumn{6}{|l|}{ Barriers to endeavor } \\
\hline Lack of Knowledge & 258 & 67.4 & 217 & 42.9 & $<0.001^{(1)}$ \\
\hline Bureaucracy & 196 & 51.2 & 157 & 31.0 & $<0.001^{(1)}$ \\
\hline Low initial return & 156 & 40.7 & 190 & 37.5 & $0.335^{(1)}$ \\
\hline Unfair competition & 61 & 15.9 & 52 & 10.3 & $0.015^{(1)}$ \\
\hline Medical-centered culture & 122 & 31.9 & 177 & 35.0 & $0.329^{(1)}$ \\
\hline Personality profile & 56 & 14.6 & 64 & 12.6 & $0.394^{(1)}$ \\
\hline Need for investment & 169 & 44.1 & 277 & 54.7 & $0.002^{(1)}$ \\
\hline Country's economic instability & 115 & 30.0 & 55 & 10.9 & $<0.001^{(1)}$ \\
\hline Lack of support & 36 & 9.4 & 68 & 13.4 & $0.064^{(1)}$ \\
\hline Lack of public policies & 40 & 10.4 & 186 & 36.8 & $<0.001^{(1)}$ \\
\hline Lack of support from class entities & 54 & 14.1 & 70 & 13.8 & $0.910^{(1)}$ \\
\hline $\begin{array}{l}\text { Lack of teaching in undergraduate } \\
\text { courses }\end{array}$ & 74 & 19.3 & 82 & 16.2 & $0.227^{(1)}$ \\
\hline Caring for is more important & 32 & 8.4 & 87 & 17.2 & $<0.001^{(1)}$ \\
\hline Convenience & 0 & 0.0 & 2 & 0.4 & $0.509^{(2)}$ \\
\hline Restriction of the field of practice & 0 & 0.0 & 1 & 0.2 & $1.000^{(2)}$ \\
\hline Lack of time & 0 & 0.0 & 1 & 0.2 & $1.000^{(2)}$ \\
\hline
\end{tabular}

To be continued
Table 1 (concluded)

\begin{tabular}{|c|c|c|c|c|c|}
\hline \multirow{3}{*}{ Variables } & \multicolumn{4}{|c|}{ Country } & \multirow{3}{*}{$\begin{array}{c}p \\
\text { value }\end{array}$} \\
\hline & \multicolumn{2}{|c|}{$\begin{array}{c}\text { Brazil } \\
(n=383)\end{array}$} & \multicolumn{2}{|c|}{$\begin{array}{c}\text { Chile } \\
(n=506)\end{array}$} & \\
\hline & $\mathbf{n}$ & $\%$ & $\mathbf{n}$ & $\%$ & \\
\hline \multicolumn{6}{|l|}{ Career possibility citation (words) } \\
\hline Related to entrepreneurial practice & 146 & 38.1 & 156 & 30.8 & $0.023^{(1)}$ \\
\hline "entrepreneur" and "endeavoring" & 21 & 5.5 & 13 & 2.6 & $0.025^{(1)}$ \\
\hline Related to home care & 117 & 30.5 & 83 & \multicolumn{2}{|c|}{$16.4<0.001^{(1)}$} \\
\hline $\begin{array}{l}\text { Related to self-employment. } \\
\text { independent or private }\end{array}$ & 20 & 5.2 & 63 & \multicolumn{2}{|c|}{$12.5<0.001^{(1)}$} \\
\hline
\end{tabular}

Concerning the pretensions for the future professional, after graduation, just over $6 \%$ claim to want to have their own business and be an entrepreneur, prevailing in both countries the intentions of continuing their studies (65.0\%) and work in public hospitals (51.6\%).

Meaningful differences were observed in the factors that condition such decisions, being greater in Brazil in relation to financial return, professional stability and possibility of putting their knowledge into practice; in Chile, to the desire to care for $(p<0.001)$.

On the reasons that would lead nurses to start their own business, entrepreneurial personality (68.3\%) and personal satisfaction (67.5\%) were considered as relevant factors in both countries, albeit with significant differences. Economic incentive with the possibility of financial return was more expressive in Brazil (78.3\%; $p<0.001)$. Significant differences were also found between the two countries regarding the possibility of putting their knowledge into practice, financing, outsourcing of health, new technologies, existence of public policies and lack of job opportunity $(p<0.05)$.

According to the perception of the investigated students, the possible barriers for a nurse to undertake are related to the lack of knowledge about entrepreneurship, most notably among Brazilians (Brazil, 67.4\%; Chile, 42.9\%; $\mathrm{p}<0.001$ ). Microeconomic issues such as the need for investment (Brazil, 40.7\%; Chile, $54.7 \%$; $\mathrm{p}=0.002$ ) and low initial financial return were relevant in both countries (Brazil, 44.1\%; Chile, 37.5\%, $p=0.335$ ).

Statistically significant differences between the countries studied were also observed in the governmental sphere, such as excessive bureaucracy for opening enterprises (Brazil 51\%; Chile $31 \%, p<0.001$ ), economic instability in the country (Brazil 30\%; Chile 11\%; $\mathrm{p}<0.001$ ), in addition to lack of public policies (Brazil 10\%; Chile 37\%; $\mathrm{p}<0.001$ ).

When asked about the possibilities of the nurse's labor market, terms related to entrepreneurship were mentioned by about one third of the interviewees, with a significant difference between the two countries $(p<0.001)$. The most employed were related to home care services and home practice.

Table 2 shows possible associations with the chance of intending to have their own business, only in Brazil, which are related to students who attend nursing in private institutions (OR 4.2, $\mathrm{Cl} 0.98$ 18.7, $\mathrm{p}=0.053)$, live with family (OR 8.457, Cl 1.121 63.823, $\mathrm{p}=0.038$ ) or with family income of up to 6,000 reais (reais is the Brazilian currency, which corresponds to an average of 1,333,33 US Dollars) (OR 5.470, Cl 1.792 16.698, p=0.003). No association was found in Chile. 
Table 2 - Bivariate associations with the chance to have their own business in Brazil and Chile

\begin{tabular}{|c|c|c|c|c|c|c|c|c|}
\hline \multirow{3}{*}{$\begin{array}{l}\text { Variables } \\
\text { Being in a private institution }\end{array}$} & \multicolumn{4}{|c|}{ Brazil } & \multicolumn{4}{|c|}{ Chile } \\
\hline & \multirow{2}{*}{$\begin{array}{c}\text { OR } \\
4.2^{*}\end{array}$} & \multicolumn{2}{|c|}{ IC95\% } & \multirow{2}{*}{$\begin{array}{c}\boldsymbol{p} \text { value } \\
0.053\end{array}$} & \multirow{2}{*}{$\begin{array}{c}\text { OR } \\
0.5\end{array}$} & \multicolumn{2}{|c|}{ IC95\% } & \multirow{2}{*}{$\frac{p \text { value }}{0.126}$} \\
\hline & & 0.98 & 18.7 & & & 0.22 & 1.2 & \\
\hline Gender & .786 & .176 & 3.506 & 0.752 & .793 & .320 & 1.967 & 0.617 \\
\hline Age & 1.146 & .953 & 1.378 & 0.146 & 1.265 & .973 & 1.645 & 0.079 \\
\hline Age group & & & & 0.295 & & & & 0.215 \\
\hline Age group 1 & 1.295 & .387 & 4.332 & 0.675 & 3.686 & .855 & 15.899 & 0.080 \\
\hline Age group 2 & 2.362 & .700 & 7.978 & 0.166 & 3.553 & .570 & 22.123 & 0.174 \\
\hline Marital status & 1.661 & .651 & 4.237 & 0.288 & 2.971 & .336 & 26.309 & 0.328 \\
\hline Family with businessman & 2.000 & .850 & 4.800 & 0.110 & 0.800 & .350 & 2.010 & 0.690 \\
\hline Children & 2.071 & .807 & 5.313 & 0.130 & 1.658 & .366 & 7.522 & 0.512 \\
\hline Type of elementary school & .730 & .262 & 2.040 & 0.549 & 1.443 & .645 & 3.232 & 0.372 \\
\hline Type of high school & .890 & .318 & 2.493 & 0.824 & .891 & .413 & 1.922 & 0.769 \\
\hline Family income & & & & 0.019 & & & & 0.416 \\
\hline Family income range 1 & $5.470^{*}$ & 1.792 & 16.698 & 0.003 & .829 & .349 & 1.967 & 0.670 \\
\hline Family income range 2 & 1.321 & .142 & 12.267 & 0.806 & 1.622 & .612 & 4.301 & 0.331 \\
\hline Family income range 3 & .000 & 0.000 & & 0.998 & & & & \\
\hline Living in an entrepreneurial city & .632 & .181 & 2.202 & 0.471 & .521 & .068 & 3.978 & 0.530 \\
\hline Working & 2.044 & .833 & 5.011 & 0.118 & 1.540 & .602 & 3.936 & 0.368 \\
\hline Work type & & & & 0.860 & & & & 1.000 \\
\hline Work type (1) & .550 & .089 & 3.408 & 0.521 & .000 & 0.000 & & 0.999 \\
\hline Work type (2) & .458 & .068 & 3.102 & 0.424 & .000 & 0.000 & & 0.999 \\
\hline Work type (3) & .491 & .084 & 2.862 & 0.429 & .000 & 0.000 & & 1.000 \\
\hline Working in health & 1.775 & .732 & 4.301 & 0.204 & 4.976 & .501 & 49.400 & 0.171 \\
\hline Living with family members & $8.457^{*}$ & 1.121 & 63.823 & 0.038 & .831 & .344 & 2.007 & 0.680 \\
\hline Living with someone & .000 & 0.000 & & 0.999 & 1.165 & .459 & & 0.747 \\
\hline Living alone & .000 & 0.000 & & 0.998 & 1.468 & .181 & 11.879 & 0.719 \\
\hline Participating in research project & .749 & .214 & 2.619 & 0.650 & 1.287 & .606 & 2.734 & 0.512 \\
\hline Scholarship grant & .972 & .347 & 2.727 & 0.957 & .660 & .303 & 1.439 & 0.296 \\
\hline
\end{tabular}

\section{DISCUSSION}

The results indicate significant differences in the profile of Brazilian and Chilean students and in the motivations studied among them, but not in the professional intentions and entrepreneurial intentions. Moreover, entrepreneurship teaching is an important factor among nursing students from both countries.

The most significant number of men attending nursing in Chile (23.3\%), compared to Brazil (11.7\%), does not reflect differences in the total population of the two countries, practically hegemonic (approximately $50 \%$ of men and women), and may be related to current social dynamics that include new family arrangements and new lifestyles transforming the traditional fields of practice of nursing professionals. Another possible explanation would be population aging, since elderly care requires physical strength and, in many cases, there is a preference for hiring men. Good pay (approximately US\$1,000) in Chile may also be attracting them to this occupation. On the other hand, it is worth noting that a profession such as nursing is still predominantly female. Entrepreneurship can and should be understood as a form of women's empowerment, overcoming gender issues, with the possibility of bringing benefits to the whole society and development to countries, even if, for this, cultural issues need to be overcome mainly in places where entrepreneurship is still considered a male aptitude (13-14). $^{\text {. }}$

The characteristics of Brazilian students mainly reflect those who attend private institutions, differing from the others in relation to: a) age - students over 30 years of age represented almost one third of the sample in these entities $(28.6 \%)$; b) many of them have children (reaches 14\%);c) most are already inserted in the labor market (62\%), working mainly in organizations and functions related to health, including as an assistant and nursing technician (56.4\%). Although training and continuing studies are entrepreneurial attitudes, the set of characteristics mentioned leads us to the possibility that this part of the studied population is in search of professional stability, with improvement in career and wages, but within the organizations where they already work and not as a profession yet to begin. These attitudes stem from the insecurity caused by political and economic crises, in addition to recessions that Brazil has been facing in recent years, contrary to what occurs in countries with economic stability, whose environment of predictability develops and the trend in investments in new businesses, innovation and technology is observed ${ }^{(15)}$.

In Chile, most students come from private schools subsidized both in elementary school (54 to 63\%) and in high school (52 to 68\%). This happens due to the government-subsidized education system, which remains even in undergraduate education through scholarships (mostly gratuity), since both the public and private universities in that country are paid. In Brazil, most students come mainly from the public school system, reaching $91 \%$ in the private $\mathrm{HEI}$ studied. Scholarships granted to Brazilian students are mainly related to federal funding of access to higher education as FIES (Fundo de Financiamento Estudantil Student Finance Fund) and PROUNI (Programa Universidade para Todos - University for All Program) in private institutions, and social demand in public universities, which are free of charge.

The high rates of insertion of academics in research projects in Chile (which reached 55\% in a private institution) are much higher than those found in Brazil, where rates did not exceed 18\%. Since 2010 there are incentive policies to improve education in Chile, which includes accreditation of universities, which is carried out in five mandatory areas: institutional management; internal quality management system; teaching and training; research, creation and innovation; and connection to the environment. Under the current higher education project, all universities need not only to teach, but also research, to function. Considering the rise of Chilean universities in international rankings, research, along with other actions, seems to have influenced this improvement. Scientific initiation through research projects gives students the opportunity to produce and reconstruct their own knowledge, developing critical and reflective thinking, besides favoring autonomy, creativity and innovation ${ }^{(16)}$, characteristics that are also inherent to entrepreneurship ${ }^{(15,17-20)}$. Moreover, promotion of scientific and critical thinking and production of new knowledge require dialogue between practice, scientific production and technological development available, which are still essential for the continuous development of nursing as a profession and a science ${ }^{(21)}$. 
With pedagogical projects focused on care of secondary and tertiary hospitals, and primary health care (PHC), Brazilian and Chilean universities seek to establish teaching and internship partnerships mainly with public organizations of these categories in the regions where they are located. Such actions seem to have repercussions on the intention to work in these institutions in the future, to the detriment of starting their own business. In Brazil, this encouragement is reinforced by legal issues such as a mandatory number of health courses being linked to the Brazilian Unified Health System (Sistema Único de Saúde, abbreviated SUS) care ${ }^{(22)}$, in addition to those related to career, which include restrictions on the areas of activity. It is worth noting that, in Chile, the universities studied pay for internship vacancies - clinical field - available in both public and private health services.

The desire to continue the studies, prevalent in both countries, seems to have different reasons. In Chile, the labor market is competitive, requiring better preparation in the search for better job opportunities and acting professionally. In Brazil, the financial return encourages to remain in the studies, since specialization and improvement programs offered to the recent graduate are financed by the Brazilian government, lasting up to two years. The Multidisciplinary Nursing Residency Program offers a monthly scholarship of 3,330.43 reais (about US\$860.00), being funded through the Ministry of Health and the Ministry of Education. In PAP (Programa de Aprimoramento Profissional), funded by the State Department of Health of São Paulo, the monthly scholarship in 2019 was 1,044.70 reais (about US\$270.00).

When relating the desire to continue studies to the home with the family, we could also infer associations in the insecurity of these students regarding the future and the need to maintain family and economic ties, thus preserving the standard of quality of life offered by parents and guardians. Young people born after 1986, also called "millennials", have generational characteristics (generation $\mathrm{Y}$ ) that require, in addition to learning, pleasure and self-realization, as well as reconciliation of personal life with obligations ${ }^{(23-24)}$. This would also explain personal satisfaction as a determining factor for the choice of the majority of students in both countries.

By conditioning their future to humanitarian reasons such as the desire to care for, more present among Chilean students, these answers reveal little discussed biases in universities. It is not an issue of disqualifying the students' altruistic motivations, but of caution in interpreting the answers, which may be more directed by the romanticized ideal about nursing due to personal and ethical conflicts, especially when it comes to a study on entrepreneurship. In this sense, a research reveals that personal values prevent the opening of business related to caring for people, since profit generates ethical conflict, that is, making money would be incompatible with the mentality of nursing services, historically more related to volunteering than to profit ${ }^{(17,25)}$.

Professional stability, predominantly pointed out by Brazilian respondents, follows a career-high culture of employment. It reflects a tendency to pursue a career in public health institutions, supporting previous studies that reveal that such choices occur mainly in countries where the State is primarily responsible for health and privatizations are less present, as occurs in Brazil with the adoption of SUS ${ }^{(17)}$.
Reduced percentages (6\%) related to entrepreneurial intentions, expressed by the claim to have their own business, portray the low entrepreneurial profile of the respondents, as reported by Roncon ${ }^{(26)}$. Studies are supported, stating that business selfefficacy, interests and career choice are less likely to arise in nursing students, as they experience more contextual (personal or financial) barriers, leading them to reject their potential entrepreneurial vocation ${ }^{(27)}$.

Although most nursing students maintain contact with enterprising family members (Brazil 37.1\%; Chile 27.6\%), absence of association with entrepreneurial intentions in this sample contradicts previous studies on subjective cultural norms that consider that family members can shape individual intention towards entrepreneurship ${ }^{(28-29)}$. Considered first generation to attend higher education, the business experience of family members experienced by most of these students are probably related to greater effort, high responsibility and low financial return, distancing themselves from the ideals of these students ${ }^{(23)}$.

Despite having a larger share of Brazilian students linked to more entrepreneurial cities, absence of significant association of this item with entrepreneurial intentions of students differs from previous investigations, such as those conducted in the United States that showed territorial differences were valid markers of real entrepreneurial behavior ${ }^{(30)}$. Nevertheless, this study can serve as basis for a set of programs and actions to influence the underlying entrepreneur culture by increasing regional economic performance in both countries in the future, as pointed out by Stuetzer ${ }^{(31)}$.

When considering the need to have an entrepreneurial personality as a reason to undertake, it is revealed the need of HEls to promote entrepreneurial skills and competences in students. Studies show that entrepreneurial profile is not only intrinsic personal traits, being possible its development since it is carried out in a transversal way, with appropriate structure and use of pedagogical methods and projects appropriate to this population ${ }^{(18,32)}$.

Economic incentive, with the possibility of financial return as a motivational factor to undertake, again reveals ethical and cultural conflicts ${ }^{(17,25)}$, suggesting that philosophical discussions should be introduced in entrepreneurship teaching. They may reveal new paths and clarify differences between dimensions that do not compete with each other, but complement each other considering that economic valuation is possible, based on pleasure in the activity of choosing as a profession. However, there is a need to better understand this phenomenon through new research, including from the point of view of the ethics of the profession.

Absence of entrepreneurial education in nursing undergraduate programs is notably perceived as barrier by students from both countries, suggesting a potential that should be explored in instances of academic education. The results support studies that indicate that universities continue to focus on patient management, but not teaching organizational management ${ }^{(25)}$. By remaining in institutional structures that prevent entrepreneurial talent in less traditionally entrepreneurial disciplines such as nursing ${ }^{(27)}$, educational centers might not respond to the future needs of the profession, which would result in nurses' unpreparedness to take over the role of entrepreneur in conducting their business ${ }^{(33)}$. A research indicates that participation in educational activities of entrepreneurship, acquired business knowledge and 
the institutional environment itself contribute positively to the entrepreneurial intentions of students ${ }^{(34)}$.

The economic issues identified as barriers to entrepreneurship in nursing, exemplified in this study as the need for initial investment, lack of funding or possible low initial financial return, support a Bangladeshi research that pointed out that economic insecurity affects the involvement of women as entrepreneurs in small and medium-sized enterprises (SME) ${ }^{(35)}$. However, studies show that many Brazilian nurses constitute companies based on low initial capital ${ }^{(20,36)}$, showing that it is possible to undertake with little investment, suggesting gaps of knowledge about the theme and the need for entrepreneurial training for these young people.

Excess bureaucracy for opening companies cited by most of the respondents, mainly in Brazil, supports studies that mention the complexity of bureaucratic processes for registration or licensing of private businesses beyond the excessive waiting time ${ }^{(14,17)}$. However, the results suggest rooting bureaucratic culture and ignorance about current policies to support entrepreneurs. It is necessary to recognize efforts already undertaken, many of them facilitated by technological advances, with simplification and debureaucratization of company registration, differentiated treatment of micro and small enterprises, simplified forms of collection of taxes and contributions, compliance with labor and social security obligations, in addition to access to credit and the market ${ }^{(36)}$.

In addition to the economic instability that creates insecurity, the lack of public policies was mentioned by most Chileans. It is expressed in the form of incentives to private practice or opening of new businesses for which no discounts, tax exemption or other similar practices are granted ${ }^{(4,17,25)}$. More open health systems, which allow diversification of health care providers, can create opportunities for nurses to undertake, just as they did in the UK and Finland through legislative and policy changes, particularly in primary medical services ${ }^{(19,37)}$.

Most of the possibilities of the labor market in the future mentioned by the students are related to self-employment, private and home practices, consistent with more daily and known activities of nurses. These activities are not understood by students as business, despite demanding self-management and entrepreneurial behavior, denoting possible differences in the meaning of "undertaking" among this population, supporting the notes of $\mathrm{GEM}^{(7)}$. On the other hand, words such as "endeavoring" and "entrepreneur" were more cited among Brazilian students, and may reflect, albeit in an incipient way, results of entrepreneurship teaching that has been included in the Brazilian public university, expanding the view of the labor market among academics.

In general, the data revealed the importance of entrepreneurship teaching in undergraduate programs, by exposing the mismatch between the perception of students and the knowledge necessary to implement an entrepreneurial culture among nurses in the countries studied. It is up to educational institutions to help broaden horizons and aspirations of young people by providing vital work-related knowledge and skills that will help them transition from school to work. They should also provide alignment between aspirations of students and real demands of the labor market, in addition to ensuring the existence of a workforce that guarantees economic prosperity in countries ${ }^{(1)}$.

Therefore, in addition to training leaders to work in health teams, there is a need to develop nurses who are also able to be both managers and employers. Undergraduate nursing education should train professionals whose possibilities can expand into business practice, and it is also necessary to disseminate teaching experiences adapted to this public.

\section{Study limitations}

In addition to the scarce literature, this study finds regional limitations of the samples studied that may not represent all students in both countries. Moreover, the study students were recruited regardless of the training period, which may have influenced entrepreneurial profile, considering that disciplines focused on this theme, when they occur, are taught in the most advanced periods of the course.

\section{Contributions to nursing, health, and public policies}

Discussions on entrepreneurship in nursing are part of more recent debates and, consequently, do not present abundant literature. By comparing comprehensively cultural issues involving Brazil and Chile, this work contributes to the expansion of understanding on the subject, being able to serve as a basis for regional development programs, to strengthen in training entrepreneurship and the underlying entrepreneurial culture, increasing local economic performance. There are still gaps to be filled in undergraduate education to prepare future professionals for the labor market and future research on the subject.

\section{CONCLUSION}

The study reveals significant differences between the two countries in the profile of students and motivations, but not in professional claims, entrepreneurial intentions and lack of teaching as an important barrier to entrepreneurship in nursing. Given the lack of entrepreneurship teaching in undergraduate nursing courses and characteristics of students in this area, educational experience must be still adequate to different cultures to better prepare future professionals for new labor markets.

\section{REFERENCES}

1. OECD/CAF/UN ECLAC., Latin American Economic Outlook 2017: Youth, Skills and Entrepreneurship. OECD Publishing. 2017. doi: 10.1787/ leo-2017-en

2. Ministério da Educação (BR). Conselho Nacional de Educação, Câmara de Educação Superior. Resolução CNE/CES n॰ 3 de 7 de novembro de 2001: Diretrizes Curriculares Nacionais do Curso de Graduação em Enfermagem. Brasília (DF): MEC [Internet]. 2001 [cited 2019 Jan 31 ]. Available from: http://http://portal.mec.gov.br/cne/arquivos/pdf/CES03.pdf 
Profile and entrepreneurial intention of nursing students: a comparison between Brazil and Chile Colichi RMB, Gómez-Urrutia V, Andres Eduardo Jimenez-Figueroa AE, Nunes HRC, Lima SAM.

3. Richter SA, Santos EP, Kaiser DE, Capellari C, Ferreira GE. Ações empreendedoras em enfermagem: desafios de enfermeiras em posição estratégica de liderança. Acta Paul Enferm. 2019;32(1):46-52. doi: 10.1590/1982-0194201900007.

4. Nikbakht-Nasrabadi A, Shabany-Hamedan M. Providing Healthcare Services at Home: a necessity in Iran: a narrative review article. Iran J Public Health [Internet]. 2016 [cited 2019 Jul 15];45(7):867-74. Available from: https://www.ncbi.nlm.nih.gov/pmc/articles/PMC4980340/pdf/JPH-45-867.pdf

5. Colichi RMB, Lima SGS, Bonini ABB, Lima SAM. Entrepreneurship and Nursing: integrative review. Rev Bras Enferm. 2019;72(Suppl 1):321-30. [Thematic Issue: Work and Management in Nursing]. doi: 10.1590/0034-7167-2018-0498

6. Parreira PMSD, Carvalho CMS, Monico LS, Santos ASMOP. Empreendedorismo no ensino superior: estudo psicométrico da escala oportunidades e recursos para empreender. Rev Psicol: Org Trab. 2017;17(4): 269-278. doi: 10.17652/rpot/2017.4.13736

7. Global Entrepreneurship Monitor (GEM). GEM 2018 / 2019 Global Report [Internet]. 2019 [cited 2019 Jul 07]. Available from: https://www. gemconsortium.org/report/gem-2018-2019-global-report

8. Global Entrepreneurship Monitor (GEM). Reporte Nacional de Chile [Internet]. 2019 [cited 2019 Jul 07]. Available from: https://negocios.udd. cl/gemchile/files/2019/06/GEM-Reporte-Nacional-de-Chile-2018-1.pdf

9. Global Entrepreneurship Monitor (GEM). Relatório Executivo Brasil [Internet]. 2019 [cited 2019 Jul 07] Avaiable from: http://datasebrae. com.br/wp-content/uploads/2019/02/Relat\%C3\%B3rio-Executivo-Brasil-2018-v3-web.pdf

10. Nabi G, Liñán F, Fayolle A, Krueger N, Walmsley A. The impact of entrepreneurship education in higher education: a systematic review and research agenda. Acad Manag Learn Edu. 2017;16(2): 277-299. doi: 10.5465/amle.2015.0026

11. Ministério Educación del Chile (CH), Servício de Información de Educación Superior. Informe Matrícula 2018 en Educación Superior en Chile. Santiago [Internet]. 2018 [cited 2019 Jul 17]. Available from: https://www.mifuturo.cl/wp-content/uploads/2018/SIES/informe\%20matricula\%20 2018_sies.pdf

12. Morais, HMM Albuquerque MSV, Oliveira RS, Cazuzu AKI, Silva NAF. Social Healthcare Organizations: a phenomenological expression of healthcare privatization in Brazil. Cad Saúde Pública. 2018;34(1). doi: 10.1590/0102-311X00194916

13. Wall S. Dimensions of precariousness in an emerging sector of self-employment: a study of self-employed nurses. Gend Work Organ. 2015;22, 221-236. doi: 10.1111/gwao.12071

14. Pittman P, Salmon ME. Advancing nursing enterprises: a cross-country comparison. Nurs Outlook. 2016;64(1):24-32. doi: 10.1016/j. outlook.2015.09.002

15. Roy R. Consulting in Occupational Health Nursing: An Overview. Workplace Health Saf. 2013;61(1);43-49. doi: 10.1177/216507991306100106

16. Moraes A, Guariente MHDM, Garanhani ML, Carvalho BG. The nurse training in research in the undergraduate education: teaching perceptions. Rev Bras Enferm. 2018;71(Suppl 4):1556-63. [Thematic issue: Education and Teaching]. doi: 10.1590/0034-7167-2017-0511

17. Jahani S, Abedi H, Elahi N, Fallahi-Khoshknab M. Iranian entrepreneur nurses' perceived barriers to entrepreneurship: a qualitative study. Iran J Nurs Midwifery Res. 2016;21(1):45-53. doi: 10.4103/1735-9066.174749

18. Boore J, Porter S. Education for entrepreneurship in nursing. Nurse Educ Today. 2011;31:184-191. doi: 10.1016/j.nedt.2010.05.016

19. Sankelo $M$, Åkerblad L. Nurse entrepreneurs' attitudes to management, their adoption of the manager's role and managerial assertiveness. $J$ Nurs Manag. 2008;16:829-36. doi: 10.1111/j.1365-2834.2008.00917.x

20. Andrade AC, Dal Ben LW, Sanna MC. Empreendedorismo na enfermagem: panorama das empresas no Estado de São Paulo. Rev Bras Enferm. 2015;68(1):40-4. doi: 10.1590/0034-7167.2015680106p

21. Bousso RS, Poles K, Cruz DALM. Nursing concepts and theories. Rev Esc Enferm USP. 2014;48(1):141-5. doi: 10.1590/ S0080-623420140000100018

22. Ministério da Educação (BR), Conselho Nacional de Educação, Câmara de Educação Superior. Resolução CNE/CES n 569 de 8 de dezembro de 2017: Princípios Gerais para as Diretrizes Curriculares Nacionais dos Cursos de Graduação da Área da Saúde. Brasília (DF): MEC [Internet]. 2017 [cited 2019 Jul 07]. Available from: https://conselho.saude.gov.br/resolucoes/2017/Reso569.pdf

23. Silva RC, Trevisan LN, Veloso EF, Dutra JS. Âncoras e valores sob diferentes perspectivas da gestão de carreira. Rev Bras Gest Neg. 2016;18(59):145-62. doi: 10.7819/rbgn.v18i59.2260

24. Gómez-Urrutia V, Royo UP, Cruz CMA. Imagining families: gender, youth, and diversity in Chile. Affilia. 2017;32(4):491-503. doi: $10.1177 / 0886109917718232$

25. Elango B, Hunter GL, Winchell M. Barriers to nurse entrepreneurship: A study of the process model of entrepreneurship. J. Am. Acad. Nurse Pract. 2007;19:198-204. Doi: 10.1111/j.1745-7599.2007.00215.x

26. Roncon PF, Munhoz S. Estudantes de enfermagem têm perfil empreendedor? Rev Bras Enferm. 2009;62(5). doi: 10.1590/ S0034-71672009000500007

27. Lanero A, Vázquez JL, Aza CL. Social cognitive determinants of entrepreneurial career choice in university students. Int Small Bus J. 2015;34(8):1053-75. doi: 10.1177/0266242615612882

28. Molino M, Dolce V, Cortese CG, Ghislieri C. Personality and social support as determinants of entrepreneurial intention: gender differences in Italy. PLoS One. 2018;13(6):e0199924. doi: 10.1371/journal.pone.0199924

29. Marques CSE, Santos G, Galvão A, Mascarenhas C, Justino E. Entrepreneurship education, gender and family background as antecedents on 
the entrepreneurial orientation of university students. Int J Innov. Sci. 2018;10(1). doi: 10.1108/IJIS-07-2017-0067

30. Obschonka M, Lee N, Rodríguez-Pose A. Big data methods, social media, and the psychology of entrepreneurial regions: capturing crosscounty personality traits and their impact on entrepreneurship in the USA. Small Bus Econ. 2019. doi: 10.1007/s11187-019-00204-2

31. Stuetzer M, Audretsch DB, Obschonka M, Gosling SD, Rentfrow JP, Potter J. Entrepreneurship culture, knowledge spillovers, and the growth of regions. Reg Stud. 2018;52(5): 603-18. doi: 10.1080/00343404.2017.1294251?journalCode=cres20

32. Amaral M, Hernandez CT, Bastos MHR. The entrepreneurial profile of Brazilian business administration students. Int J Innov Sci. 2018;10(2):160-177. doi: 10.1108/JIS-05-2017-0040

33. Hau ML. Ten common mistakes to avoid as an independent consultant: an update. Workplace Health Saf. 2013;61(1);11-8. doi: $10.1177 / 216507991306100103$

34. Küttim M, Kallastea M, Venesaara U, Kiisb A. Entrepreneurship education at university level and students' entrepreneurial intentions. Procedia Soc Behav Sci. 2014;110:658-68. doi: 10.1016/j.sbspro.2013.12.910

35. Hossain A, Siddique ZR, Jamil AA. Factors affecting women involvement as entrepreneur in SMEs sector, economic development and its impact on poverty reduction in Bangladesh. Bus, Manag Econ Res [internet]. 2018 [cited 2019 Jul 15];4(5):51-65. Avaiable from: https:// arpgweb.com/pdf-files/bmer4(5)51-65.pdf

36. Colichi RMB, Lima SAM Entrepreneurship in Nursing compared to other health professions. Rev Eletrôn Enferm. 2018;20(20a11). doi: 10.5216/ree.v20.49358

37. Drennan V, Davis K, Goodman C, Humphrey C, Locke R, Mark A, Murray SF, Traynor M. Entrepreneurial nurses and midwives in the United Kingdom: an integrative review. J Adv Nurs. 2007;60:459-69. doi: 10.1111/j.1365-2648.2007.04458.x 